\title{
Recurrent Ampulla of Vater Adenocarcinoma
}

National Cancer Institute

\section{Source}

National Cancer Institute. Recurrent Ampulla of Vater Adenocarcinoma. NCI Thesaurus. Code C153574.

The reemergence of ampulla of Vater adenocarcinoma after a period of remission. 